Ricardo in his Thomas Lowe Gray lecture to the Institution of Mechanical Engineers delivered on December 1, marine engineers will see yet another great change. Though he could not make out a case for a Diesel engine of any sort in really large or very fast vessels, Mr. Ricardo urged that for ships up to 6,000 horse-power, the power plants might well consist of a very large number of light high-speed Diesel engines, driving electric generators supplying the current necessary for the propulsion motors and for auxiliary purposes. One of the outstanding features in engineering practice of recent times is the marked success of the high-speed Diesel engine for road transport. During the last two years, some 20,000 engines aggregating more than 2,000,000 horse-power have been put into service on the roads of Europe. These engines range up to 150 horsepower, and 70-80 such engines could easily be installed in groups and tiers for a vessel of 6,000 horse-power. The fuel supply, the circulating water and lubricating oil could be supplied from a central station and engines could be started and stopped from a central control. Mr. Ricardo sees no difficulty in the maintenance of such a plant, for the units could be easily disconnected and hoisted out and the engines overhauled regularly at a shore depot. To overcome the noise difficulty, each unit would be enclosed in a double-walled wooden sound-proof box. 'Thus enclosed, the generating sets will sound like bees on a summer's afternoon, and the solitary engine room clerk will be able to smoke his pipe of peace." Fanciful as the scheme appears to be, it is by no means an impossible one and it would be of interest to see it put to the test.

\section{Slaughter-House Reform}

Prof. J. H. Jones delivered the twelfth annual Benjamin Ward Richardson Memorial lecture on November 30 before the Model Abattoir Society, his subject being slaughter-house reform. He said that slaughtering is at present conducted in small private slaughter-houses or in municipal slaughter-houses. The former are often inefficient inasmuch as the scale of organisation prevents the proper utilisation of by-products and in other ways adds to expenses. There are also serious disadvantages connected with municipal slaughter-houses, as not only are they on too small a scale, but also they are merely a collection of stalls for private butchers. In view of the wastefulness of the present system, the Committee of the Economic Advisory Council on the Slaughtering of Livestock, of which Prof. Jones is a member, has recommended a scheme based on regional monopoly. It has recommended the appointment of a National Slaughter-Houses Board, that is, a statutory non-profit-making body to prepare regional shemes to be operated by regional authorities, which might be either joint boards of local authorities or existing associations prepared to provide their own finances. The regional authority would provide the service of the slaughter of animals and the transport of meat to the centres of retail distribution. It would not itself purchase animals and sell meat; on the other hand, it would purchase and itself work up the by-products. It might appear at first sight to create a new departure by establishing a monopoly of slaughtering within each of the selected regions, but monopoly is already a privilege of the municipal slaughter-houses of Scotland and in a few of them a serious attempt is being made to utilise by-products. The recommendations appear to be in line with modern British development and to provide a scheme which would be both efficient on the technical side and likely to improve the inspection of meat and humane slaughter. The scheme would not apply to the trade in Kosherkilled meat.

\section{International Committee on Intellectual Co-operation}

THE report of the International Committee on Intellectual Co-operation on the work of its fifteenth plenary session, which contains extracts from the general report of the director of the International Institute of Intellectual Co-operation, indicates the work done in this field, alike in the service of the various States, of the League of Nations, and of intellectual activities for their own sake, the service of ideas, of the mind. During the year, the Institute has continued to concentrate on the collaboration of qualified experts or competent international committees. Thus, arising out of Prof. Shotwell's proposal, a preliminary inquiry has been commenced on collective security and on the collection of data regarding the progress in various countries towards the encouragement of the study of legal, social and political sciences, which should issue in a scientific contribution to the work of the League. The material required for the publication of a repertory of scientific laboratories has been collected. The committee of experts dealing with the co-ordination of scientific terminology has examined in detail various terms responsible for misunderstanding or controversy between chemists and physicists, and established definitions which will be communicated to the International Unions of Physics and Chemistry and to the International Council of Scientific Unions for final approval. Technical recommendations relating to neologisms have also been formulated and various steps taken towards collaboration between science museums, including the publication of a periodical information bulletin, Scientific Museums, while the inquiry on documentation has been vigorously pursued.

\section{Effect of Economy Cuts in the United States}

A RECENT article in Industrial and Engineering Chemistry (News Edition, Nov. 10, p. 315) reviews the results of the recent economy cuts in chemical research at Washington. On the whole, the results of the Economy Act have been less devastating than at first threatened. Most bureaux were able to continue on a reduced scale; the danger of dilution of personnel with political nominees has been entirely avoided in the scientific branches; the chief effect has been the dropping of less essential projects, and a retardation of progress, with drastic reductions in only one or two departments. Chemical research is centred mainly in the Department of Agriculture and in the 